\title{
SISTEM RECOMMENDER PROGRAM STUDI FMIPA MENGGUNAKAN METODE PREFERENCE RANGKIN ORGANIZATION FOR ENRICHMENT EVALUATION (PROMETHEE)
}

\author{
Linda Marlinda ${ }^{1, a)}$, Sulistianto SW ${ }^{2, b)}$ \\ 1,2 Teknik Informatika, STMIK Nusa Mandiri Jakarta Kramat Raya 18 Jakarta pusat 10420 \\ Email: ${ }^{a}$ linda.ldm@nusamandiri.ac.id, b)sulistianto.sow@nusamandiri.ac.id
}

\begin{abstract}
Abstrak
Pemilihan program studi memainkan peran penting dalam keberhasilan seseorang untuk menentukan masa depannya. Salah satu risiko yang terkait dengan pemilihan studi adalah ketidaksesuaian dengan kebutuhan lowongan pekerjaan saat ini di perusahaan yang secara signifikan mempengaruhi masa depan siswa tersebut. Karena ada banyak kriteria yang harus diperhatikan, maka melalui sistem recommender ini, siswa dapat mengetahui apa bidang yang paling tepat untuk mereka. Sistem ini dibangun berdasarkan metode PROMETHEE. Ketika seorang siswa mengisi kuesioner, ia harus konsisten dengan jawabannya untuk mendapatkan output terbaik berdasarkan kemauan dan karakteristik nya. Penelitian ini menggunakan metode analisis deskriptif menyajikan ringkasan hasil survei dan wawancara dari calon mahasiswa yang ingin memilih program studi khususnya FMIPA di beberapa perguruan tinggi sesuai dengan kodifikasi yang terhubung dengan Job Career sehingga dapat menjadi acuan untuk calon mahasiswa dalam mencari pekerjaan.
\end{abstract}

Kata-kata kunci: Sistem Recommender, Program Studi, Multikriteria, Promethee

\begin{abstract}
The selection of study programs plays an important role in one's success to determine his future. One of the risks associated with choosing a study is the incompatibility with current job vacancy needs of a company that significantly affects the student's future. Because there are many criteria to be considered, then through this recommender system, students can find out what areas are most appropriate for them. The system is built on the PROMETHEE method. When a student fills out a questionnaire, he / she must be consistent with his / her answer to get the best output based on his / her will and characteristics. This study uses a descriptive analysis method presents a summary of survey results and interviews of prospective students who want to choose a study program, especially FMIPA in several universities in accordance with the codification connected with Job Career so that it can be a reference for prospective students in finding a job.
\end{abstract}

Keywords: System Recommender, Study Program, Multikriteria, Promethee 


\section{PENDAHULUAN}

Melanjutkan studi di perguruan tinggi, mungkin menjadi suatu harapan yang besar bagi setiap orang. Untuk mencapai harapan tersebut, segala usaha dan persiapan dilakukan sejak dini. Pada kenyataannya tidak semua orang dapat merasakan kuliah ditempat yang favorit, paling tidak karena alasan ekonomi atau tidak lulus dalam tes seleksi di perguruan tinggi negri. Banyak calon mahasiswa baru kesulitan untuk memilih program studi yang diinginkan pada saat mereka mendatangi unversitas yang diinginkan. Dikarenakan perguruan tinggi tersebut banyak membuka program studi, tetapi minim sekali informasi yang diberikan untuk calon mahasiswa baru tersebut. Jika perguruan tinggi memberikan banyak informasi mungkin memudahkan para calon untuk memilih program studi yang ingin sesuai dengan output yang diharapkan bagi masa depan calon mahasiswa baru. Dengan cara memberikan gambaran program studi yang dibuka oleh perguruan tinggi melalui web kampus atau buku panduan akademik yang diberikan kepada calon mahasiswa baru pada saat ingin mendaftar.

Faktor yang mempengaruhi dalam pemilihan program studi terdiri dari enam faktor yaitu bakat, minat, jurusan sekolah asal, karir atau stakeholder yang diperlukan oleh perusahaan, pilihan orangtua dan biaya program studi.

Penelitian ini bertujuan membangun sebuah recommender system yang dapat memberikan rekomendasi pemilihan program studi FMIPA yang terdiri dari Biologi, Fisika, Matematika dan Kimia terdapat di wilayah kopertis III, sesuai dengan faktor faktor kriteria dari calon mahasiswa baru dan juga dapat memberikan rekomendasi bagi lulusan mahasiswa program studi apa yang dibutuhkan oleh perusahaan saat ini.

\section{Recommender System}

Menurut (Losee, 1998), Kinerja yang diharapkan peringkat yang diusulkan model tersebut dapat dihitung, diberi nilai parameter tertentu. serta mungkin memperkirakan probabilitas pesan dengan serangkaian fitur yang relevan Mengingat data historis, dapat langsung menghitung dan, serta parameter yang diperlukan untuk menghitung fitur probabilitas pada salah satu penggunaan model ini adalah untuk memperkirakan jumlah pesan yang relevan yang tersedia. Jika ingin mengetahui jumlah yang diharapkan. Serta mewakili probabilitas relevansi untuk membantu pengguna dalam menentukan kapan harus berhenti memeriksa pesan. Pada setiap tahap dalam proses pemeriksaan pesan, adalah mungkin untuk menghasilkan grafik tersebut, menunjukkan kualitas yang diharapkan dari kedua diperiksa dan pesan teruji, mengingat perkiraan parameter saat ini. untuk berhenti memeriksa pesan. Ketidakakuratan dalam grafik disebabkan oleh ketidak akuratan dalam parameter perkiraan. Kesalahan ini harus menurun karena lebih banyak pesan yang diperiksa dan lebih pesan untuk masing-masing kelas relevansi tersedia untuk perhitungan parameter perkiraan.

Menurut (Adomavicius, 2005) Sistem recommender adalah sistem yang rekomendasikan fokus permasalahan yang secara eksplisit mengandalkan pada peringkat struktur. Dalam rumusan yang paling umum, masalah rekomendasi dikurangi menjadi masalah memperkirakan pemberian peringkat untuk item yang belum pernah dilihat oleh seorang pengguna. Intuitif, estimasi ini biasanya didasarkan pada peringkat yang diberikan oleh user untuk barang-barang lain dan pada beberapa lainnya informasi yang akan dijelaskan di bawah ini secara resmi. Setelah dapat memperkirakan pemberian peringkat untuk yang belum terrangking, dapat merekomendasikan kepada pengguna item (s) dengan tertinggi diperkirakan rating (s).

Recommender system sendiri dapat didefinisikan sebagai sistem yang menghasilkan rekomendasi individual sebagai keluaran atau sistem yang memiliki efek untuk membimbing user dengan cara yang personal untuk memilih objek yang menarik dan berguna di antara banyaknya kemungkinan pilihan (Burke, 2002).

\section{Multi Criteria Decision Making (MCDM)}

Keputusan merupakan rangkaian tindakan yang perlu diikuti dalam memecahkan masalah untuk menghindari atau menguarangi dampak negatif, atau untuk memanfaatkan kesempatan yang ada. Pengambilan keputusan yang dilakukan oleh organisasi atau individu telah banyak membantu dalam 
mempertahankan keberadaan suatu organisasi atau individu yang telah banyak membantu dalam pemecahan masalah dalam melakukan aktifitasnya.

Dalam sistem recommender, item minat dan preferensi pengguna diwakili dalam berbagai bentuk. Sistem ini menggunakan satu atau beberapa atribut untuk menggambarkan item. Terutama dalam sistem di mana rekomendasi didasarkan pada pendapat orang lain, adalah penting untuk mempertimbangkan beberapa kriteria yang mempengaruhi pengguna sehingga dapat membuat rekomendasi yang lebih efektif. Meskipun sistem telah recommender telah melakukan beberapa atribut untuk produksi rekomendasi, penelitian tentang cara Multi-Criteria Decision Making (MCDM) metode dapat memfasilitasi proses membuat rekomendasi mungkin masih dianggap sporadis.

Sebagian pengamatan ini bertentangan dengan kenyataan bahwa dalam literatur, ada recommender beberapa proposal untuk sistem yang menggunakan metode MCDM. Sistem seperti ini dapat disebut sebagai multi-kriteria sistem recommender adalah sebagai berikut:

1. Untuk mengidentifikasi dimensi yang diusulkan oleh taksonomi yang ada dan atau recommender kategorisasi sistem, dan mengklasifikasikan mereka ke dalam kumpulan dimensi yang dapat digunakan untuk mempelajari sistem seperti ini.

2. Untuk meningkatkan dikumpulkan set dimensi dengan dimensi yang berhubungan dengan multi-kriteria rekomendasi, dan untuk merumuskan kerangka kerja menyeluruh yang mungkin juga digunakan untuk studi multi-kriteria sistem recommender.

3. Untuk menyediakan analisis dan klasifikasi dari multi-kriteria yang ada recommender sistem, sesuai dengan kerangka kerja yang diusulkan.

MCDM merupakan teori pengambilan keputusan yang mempertimbangkan sekumpulan alternatif pilihan yang terbatas terhadap kriteria yang banyak. Permasalahan MADM dapat diformulasikan sebagai berikut: Dimisalkan ada sejumlah $\mathrm{M}$ kriteria dan $\mathrm{N}$ alternatif, dimana adalah kriteria dan adalah alternatif maka akan dipilih sebuah atau sekumpulan alternative yang memenuhi kriteria semaksimal mungkin (Fulop, 2007). Permasalahan MADM dapat dimodelkan dalam bentuk matriks keputusan (decision matrix)

Tabel 1. Matriks Keputusan

\begin{tabular}{cccccc}
\multicolumn{8}{c}{ Criteria } \\
\hline \multicolumn{1}{c}{$\mathrm{C}_{1}$} & $\mathrm{C}_{2}$ & $\mathrm{C}_{3}$ & & $\mathrm{C}_{\mathrm{N}}$ \\
Alternatif & $\mathrm{W}_{1}$ & $\mathrm{~W}_{2}$ & $\mathrm{~W}_{3}$ & $\ldots \ldots$ & $\mathrm{W}_{4}$ \\
\hline $\mathrm{A}_{1}$ & $\mathrm{a}_{11}$ & $\mathrm{a}_{12}$ & $\mathrm{a}_{13}$ & $\ldots \ldots$ & $\mathrm{a}_{1 \mathrm{~N}}$ \\
$\mathrm{~A}_{2}$ & $\mathrm{a}_{21}$ & $\mathrm{a}_{22}$ & $\mathrm{a}_{23}$ & $\ldots \ldots$ & $\mathrm{a}_{2 \mathrm{~N}}$ \\
$\mathrm{~A}_{3}$ & $\mathrm{a}_{31}$ & $\mathrm{a}_{32}$ & $\mathrm{a}_{33}$ & $\ldots \ldots$ & $\mathrm{a}_{3 \mathrm{~N}}$ \\
$\cdot$ & $\cdot$ & $\cdot$ & $\cdot$ & $\ldots \ldots$ & $\cdot$ \\
$\cdot$ &. &. &. & $\ldots \ldots$ & $\cdot$ \\
$\cdot$ & $\cdot$ & $\cdot$ &. & $\ldots \ldots$ & $\cdot$ \\
$\mathrm{A}_{\mathrm{M}}$ & $\mathrm{a}_{\mathrm{M} 1}$ & $\mathrm{a}_{\mathrm{M} 2}$ & $\mathrm{a}_{\mathrm{M} 3}$ & $\ldots \ldots$. & $\mathrm{a}_{\mathrm{MN}}$ \\
\hline
\end{tabular}

Matriks keputusan merupakan matriks berukuran $\mathrm{M} \times \mathrm{N}$ dimana elemen aij mengindikasikan performansi alternatif Ai ketika dievaluasi terhadap kriteria $\mathrm{Cj}$ (untuk $\mathrm{i}=1,2,3, \ldots, \mathrm{M}$ dan $\mathrm{j}=$ $1,2,3, \ldots, N)$. Ada Gambar dibawah ini menunjukan hubungan yang digunakan untuk menganalisis dan mengkalsifikasikan recommender multi kriteria sistem (Manouselis, 2007).

\section{Metode Promethee}

Suatu metode penentuan urutan (prioritas) dalam analisis multikriteria. Masalah pokoknya adalah kesederhanaan, kejelasan, dan kestabilan. Dugaan dari dominasasi kriteria yang digunakan 
dalam Promethee adalah penggunaan nilai dalam hubungan outrangking. Semua parameter yang dinyatakan mempunyai pengaruh nyata menurut pandangan ekonomi (Brans et. al, 1986).

Promethee menyediakan kepada user untuk menggunakan data secara langsung dalam bentuk tabel multikriteria sederhana. Promethee mempunyai kemampuan untuk menangani banyak perbandingan, pengambil keputusan hanya mendefenisikan skala ukurannya sendiri tanpa batasan, untuk mengindikasi prioritasnya dan preferensi untuk setiap kriteria dengan memusatkan pada nilai (value), tanpa memikirkan tentang metode perhitungannya.

Metode Promethee menggunakan kriteria dan bobot dari masing-masing kriteria yang kemudian diolah untuk menentukan pemilihan alernatif lapangan, yang hasilnya berurutan berdasarkan prioritasnya.

Penggunaan metode Promethee dapat dijadikan metode untuk pengambilan keputusan di bidang pemasaran, sumber daya manusia, pemilihan lokasi, atau bidang lain yang berhubungan dengan pemilihan alternatif.

Metode penentuan urutan atau prioritas dalam analisis multikriteria atau MCDM (Multi Criteria Decision Making). Promethee merupakan metode dalam memecahkan permasalahan yang bersifat multikriteria dengan cara menentukan urutan (prioritas). Masalah pokoknya adalah kesederhanaan, kejelasan , dan kestabilan.

Dugaan dari dominasi kriteria yang digunakan dalam Promethee adalah penggunaan nilai dalam hubungan outranking. Ini adalah metode peringkat yang cukup sederhana dalam konsep dan aplikasi dibandingkan dengan metode lain untuk analisis multikriteria.

Tabel 2. Data Dasar Analisis PROMETHEE

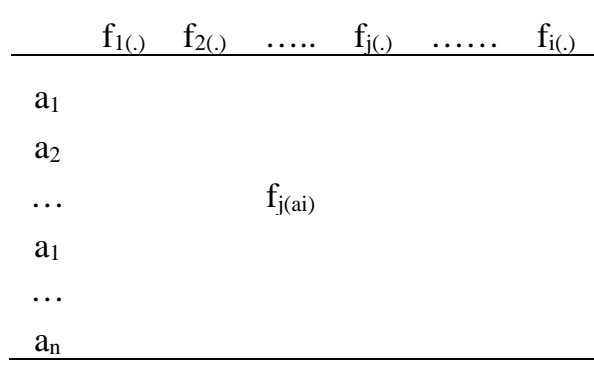

\section{Dominasi Kriteria}

Nilai f merupakan nilai nyata dari suatu kriteria, $f: K \rightarrow Я$ (Real Word).

Penyampaian Intensitas (P) dari preferensi alternatif a terhadap alternatif b yaitu:

- $\mathrm{P}(\mathrm{a}, \mathrm{b})=0$, berarti tidak ada beda antara a dan $\mathrm{b}$, atau tidak ada preferensi dari a lebih baik dari b.

- $\quad \mathrm{P}(\mathrm{a}, \mathrm{b}) \approx 0$, berarti lemah preferensi dari a lebih baik dari $\mathrm{b}$.

- $\mathrm{P}(\mathrm{a}, \mathrm{b})=1$, kuat preferensi dari a lebih baik dari b.

- $\mathrm{P}(\mathrm{a}, \mathrm{b}) \approx 1$, berarti mutlak preferensi dari a lebih baik dari $\mathrm{b}$.

Dalam metode ini fungsi preferensi seringkali menghasilkan nilai fungsi yang berbeda antara dua evaluasi, sehingga : $\mathrm{P}(\mathrm{a}, \mathrm{b})=\mathrm{P}(\mathrm{f}(\mathrm{a})-\mathrm{f}(\mathrm{b}))$.

rumus perhitungan bobot kriteria :

$$
W_{j}=\frac{w_{j}}{\sum w_{i}} \text { atau } \sum W_{j}=1
$$

Maka didapat rumus perbandingan untuk setiap alternatif, sebagai berikut :

$$
\pi\left(a_{1}, a_{i}\right)=\sum_{j=1}^{J} W_{j} \times P_{j}\left(a_{1}, a_{i}\right)
$$


Promethee berfungsi untuk mengolah data, baik data kuantitatif dan kualitatif sekaligus. Dimana semua data digabung menjadi satu dengan bobot penilaian yang telah diperoleh melalui penilaian atau survey.

Langkah-langkah perhitungan dengan metode Promethee adalah sebagai berikut :

1. Menentukan beberapa alternatif

2. Menentukan beberapa kriteria

3. Menentukan dominasi kriteria

4. Menentukan tipe penilaian, dimana tipe penilaian memiliki 2 tipe yaitu; tipe minimum dan maksimum.

5. Menentukan tipe preferensi untuk setiap kriteria yang paling cocok didasarkan pada data dan pertimbangan dari decision maker. Tipe preferensi ini berjumlah Enam (Usual, Quasi, Linear, Level, Linear Quasi dan Gaussian).

6. Memberikan nilai threshold atau kecenderungan untuk setiap kriteria berdasarkan preferensi yang telah dipilih.

7. Perhitungan Entering flow, Leaving flow dan Net flow.

8. Hasil pengurutan hasil dari perangkingan antara lain :

a. Perangkingan parsial yang didasarkan pada nilai Entering flow dan Leaving flow.

b. Perangkingan lengkap atau komplit yang didasarkan pada nilai Net flow.

Perangkingan dalam metode PROMETHEE terdiri dari:

1. Entering flow, arah mendekat dari node a dan hal ini merupakan karakter pengukuran outrangking. Untuk setiap nilai node a dalam grafik nilai outrangking ditentukan berdasarkan entering flow dengan persamaan:

$$
\phi^{+}\left(a_{1}\right)=\sum_{i=1}^{I} \pi\left(a_{1}, a_{i}{ }^{\prime}\right)
$$

2. Leaving flow, jumlah dari yang memiliki arah menjauh dari node a. dan hal ini merupakan pengukuran outrangking. dengan persamaannya:

$$
\phi^{-}\left(a_{1}\right)=\sum_{i=1}^{I} \pi\left(a_{1} ; a_{i}\right)
$$

3. Net Flow, Sehingga pertimbangan dalam penentuan Net flow diperoleh dengan persamaan:

$$
\phi\left(a_{1}\right)=\phi^{+}\left(a_{1}\right)-\phi^{-}\left(a_{1}\right)
$$

\section{Keterangan}

1. $\quad f(a, x)=$ menunjukkan preferensi bahwa alternatif lebih baik dari alternatif $x$.

2. $\quad \mathrm{f}(\mathrm{x}, \mathrm{a})=$ menunjukkan preferensi bahwa alternatif $\mathrm{x}$ lebih baik dari alternatif

3. $\mathrm{F}+(\mathrm{a})=$ Leaving flow, digunakan untuk menentukan urutan prioritas pada proses Promethee I yang menggunakan urutan parsial.

4. $\quad$ F-(a) = Entering flow, digunakan untuk menentukan urutan prioritas pada proses Promethee I yang menggunakan urutan parsial.

5. $\quad F(a)=$ Net flow, digunakan untuk menghasilkan keputusan akhir penentuan Urutan dalam menyelesaikan masalah sehingga menghasilkan urutan lengkap.

\section{METODE PENELITIAN}

\section{Sampling/Metode Pemilihan Sampel}

Dalam penelitian ini data dan informasi dikumpulkan dari responden calon mahasiswa baru dengan menggunakan teknik wawancara, pengamatan dan pengisian secara langsung pada Recommender System pemilihan program studi FMIPA yang akan dipilih. Diharapkan setelah melakukan penelitian ini calon mahasiswa baru dapat memilih program studinya secara tepat sesuai dengan yang diinginkannya, berdasarkan alternatif peringkat pembobotan yang diperoleh, sehingga dapat meminimalisasi kegagalan atau tidak sesuaiannya pengisian pada aplikasi Recommender System pemilihan program studi. 


\section{Metode Pengumpulan Data}

Penelitian diawali dengan melakukan analisa kebutuhan dan membuat model dalam bentuk kuesioner. Selanjutnya kuesioner ini diberikan kepada beberapa responden yang bertindak sebagai pakar. Dimana proses pengumpulan data primer responden melalui survei dan wawancara langsung di lapangan sesuai dengan kebutuhan dan kondisi yang ada berdasarkan pemilihan program studi yang ingin dipilih oleh calon mahasiswa pada saat ingin mendaftar.

Instrumentasi

Model yang dipilih, didasari atas model Promethee yang dikembangkan dalam model Recommender System pemilihan program studi. Struktur yang diajukan dalam penelitian terdiri dari:

a. Kriteria yang berisi bakat, minat, jurusan, karir, pilihan orang tua, biaya

b. Alternatif yang berisi fisika, kimia, matematika, biologi.

c. Dengan pembagian sebagai berikut:

Pada penelitian yang menggunakan metode Promethee ini terdapat empat hal yang menjadi perhatian khusus yaitu penentuan criteria yang akan digunakan, pembobotan nilai untuk setiap criteria, serta alternative yang ada. (Benarkah, 2009).

Recommender system yang dibuat berdasarkan penelitian terhadap responden siswa SMA sederajat yang mengalami kesulitan dalam memilih program studi yang beragam yang dibuka oleh perguruan tinggi di wilayah kopertis wilayah III, sehingga mempermudah pengguna dalam memilih program studi yang diinginkan berdasarkan kebutuhan perusahaan saat ini. Adapun kriteriakriterianya, adalah :

F1 Bakat

F2. Minat

F3 Jurusan asal Sekolah

F4. Karir

F5. Pilihan Orang Tua

F6. Biaya

Simbol Alternatif atau alternatif yang digunakan:

A1. Fisika

A2. Kimia

A3. Biologi

A4. Matematika

Simbol hasil perhitungan :

LF : Leaving flow

EF : Entering flow

NF : Net flow

\section{HASIL DAN PEMBAHASAN}

1. Penelitian diawali dengan pengamatan penerapan system recommender pemilihan Program studi yang bertujuan untuk meminimalisasi kesalahan yang akan ditimbulkan akibat dari kegagalan pemilihan program studi. Penelitian ini menggunakan metode deskriptif analitik dengan menyajikan rangkuman hasil survei dan wawancara yang berupa kuesioner secara manual (penelitian sebelumnya).

2. Analisis Kebutuhan, Data input yang digunakan data hasil pengolahan kuesioner dan data analisis.

3. Kebutuhan proses, dibutuhkan untuk memproses data input menjadi data output berupa informasi yang diinginkan yaitu, Proses menghitung untuk nilai parameter, Proses menghitung nilai Leaving flow, Proses menghitung nilai Entering flow dan Proses menghitung nilai net flow

4. Kebutuhan output yang diinginkan menjadi referensi bagi calon mahasiswa baru dalam memilih program studi FMIPA yang akan dipilih. 
5. Sumber data berasal dari internal maupun external calon mahasiswa baru dan program studi.

6. Rancangan Model menggunakan promethee dengan penentuan alternative yang dipilih dan paling diminati diantaranya fisika, kimia, biologi dan matematika dengan menentuan perangkingan dalam metode promethee yaitu memberikan nilai/bobot untuk masing-masing criteria. Ada 4 jenis nilai pembobotan yang ditetapkan, yaitu 1 (prioritas rendah) sampai dengan 4 (sangat diprioritaskan).

7. Penentuan parameter, Parameter yang berlaku pada setiap preferensi akan berbeda, mengikuti preferensi yang dipilih yaitu q dan p. Nilai parameter dari tiap preferensi ditentukan oleh decision maker dengan memperhatikan batasan yang sesuai untuk masingmasing kriteria. Pada Tabel 3. diberikan desain kuisioner untuk pengambilan sampel data

Tabel 3. Kuisioner

\begin{tabular}{|c|c|c|c|c|c|c|c|}
\hline \multirow[b]{2}{*}{ No } & \multirow{2}{*}{$\begin{array}{l}\text { Program } \\
\text { Studi }\end{array}$} & \multicolumn{6}{|c|}{ Kriteria } \\
\hline & & Bakat & Minat & $\begin{array}{c}\text { Jurusan / Asal } \\
\text { sekolah }\end{array}$ & Karir & $\begin{array}{c}\text { Pilihan } \\
\text { Orang Tua }\end{array}$ & Biaya \\
\hline 1 & Fisika & & & & & & \\
\hline 2 & Kimia & & & & & & \\
\hline 3 & Matematika & & & & & & \\
\hline 4 & Biologi & & & & & & \\
\hline
\end{tabular}

Setelah hasil kuisioner didapat maka data tersebut dimasukan kedalam beberapa kriteria yang sudah ditentukan, adapun kriterianya sebagai berikut: f1(.) : Bakat, f2(.) : Minat, f3(.) : Jurusan asal Sekolah, f4(.) : Karir, f5(.) : Pilihan Orang Tua, f6(.) : Biaya.

8. Langkah selanjutnya adalah dilakukannya analisa preferensi dengan cara menghitung nilai preferensi criteria dari preferensi multikriteria dari setiap alternative. Hasil dari analisa preferensi akan digunakan untuk menghitung nilai Leaving Flow, Entering Flow dan Net Flow dari setiap alternative. Nilai Net flow terbesar menunjukan bahwa alternative tersebut merupakan alternative yang sangat diprioritaskan untuk memilih jurusan, dan bagi yang nilai Net flow nya terkecil menunjukan bahwa alternative tersebut merupakan alternative dengan prioritas rendah atau tidak direkomendasikan. Terdiri dari : Bakat, Minat, Jurusan asal Sekolah, Karir, Pilihan Orang Tua dan Biaya.

9. Penentuan Parameter, Parameter yang berlaku pada setiap preferensi akan berbeda, mengikuti preferensi yang dipilih yaitu q dan p. Nilai Parameter dari tiap preferensi ditentukan oleh Decision Maker dengan memperhatikan batasan yang sesuai untuk masingmasing kriteria. Pada Tabel 4 diberikan Desain Kuisioner untuk pengambilan sampel data. Data dapat dilihat pada Tabel 4.

Table 4. Nilai Kriteria Masing Masing Alternatif Data Hasil Kuisioner

\begin{tabular}{|c|c|c|c|c|c|c|c|c|c|}
\hline \multirow{2}{*}{ Kriteria } & \multirow{2}{*}{$\begin{array}{c}\text { Min } \\
\text { Maks }\end{array}$} & \multirow[t]{2}{*}{ Bobot } & \multicolumn{4}{|c|}{ Alternatif } & \multirow{2}{*}{$\begin{array}{c}\text { Tipe } \\
\text { Preferensi }\end{array}$} & \multicolumn{2}{|c|}{ Parameter } \\
\hline & & & Fisika & Kimia & Matematika & Biologi & & $\mathbf{q}$ & $\mathbf{p}$ \\
\hline Bakat & Min & 0.2 & 50 & 30 & 40 & 50 & 4 & 50 & 70 \\
\hline Minat & Max & 0.2 & 70 & 40 & 40 & 30 & 3 & & 20 \\
\hline $\begin{array}{l}\text { Jurusan Asal } \\
\text { sekolah }\end{array}$ & Max & 0.25 & 10 & 10 & 9 & 8 & 3 & & 2 \\
\hline Karir & Max & 0.15 & 70 & 60 & 50 & 50 & 5 & 30 & \\
\hline $\begin{array}{l}\text { Pilihan } \\
\text { orang tua }\end{array}$ & Min & 0.1 & 1 & 5 & 2 & 4 & 2 & 2 & 1 \\
\hline Biaya & Max & 0.1 & 36 & 48 & 48 & 60 & 1 & & \\
\hline
\end{tabular}


10. Penentuan Indeks Preferensi, Setelah data didapat maka dibuatkanlah matriks data indeks preferensi yang sudah melalui tahapan-tahapan perhitungan dalam menentukan nilai indeks preferensi yang disajikan pada Tabel 5 .

Tabel 5. Indeks Preferensi

\begin{tabular}{ccccccc}
\hline Alternatif & A1 & A2 & A3 & A4 & Jumlah & Leaving \\
\hline A1 & 0 & 0.2 & 0.125 & 0.5 & 0.825 & 0.275 \\
A2 & 0.3 & 0 & 0.225 & 0.45 & 0.975 & 0.325 \\
A3 & 0.2 & 0.25 & 0 & 0.475 & 0.925 & 0.308333 \\
A4 & 0.1 & 0.1 & 0.1 & 0 & 0.3 & 0.1 \\
Jumlah & 0.6 & 0.55 & 0.45 & 1.425 & & \\
Entering & 0.2 & 0.1833 & 0.15 & 0.475 & & \\
\hline
\end{tabular}

11. Penentuan Nilai Leaving Flow, Entering Flow dan Net Flow, Setelah perhitungan indeks preferensi selesai berdasarkan data matriks diatas maka selanjutnya menghitung nilai Leaving Flow, Entering Flow dan Net Flow. Adapun nilai-nilainya dapat dilihat pada Tabel 6.

Tabel 6. Nilai Leaving Flow, Entering Flow dan Net Flow

\begin{tabular}{ccccc}
\hline Alternatif & $\begin{array}{c}\text { Leaving } \\
\text { Flow }\end{array}$ & $\begin{array}{c}\text { Entering } \\
\text { Flow }\end{array}$ & Net Flow & Urutan \\
\hline Fisika & 0.275 & 0.2 & 0.075 & 3 \\
Kimia & 0.325 & 0.183 & 0.1416 & 2 \\
Matematika & 0.3083 & 0.15 & 0.1583 & 1 \\
Biologi & 0.1 & 0.475 & -0.375 & 4 \\
\hline
\end{tabular}

\section{SIMPULAN}

Recommender System merupakan sistem yang menghasilkan rekomendasi individual sebagai keluaran atau sistem yang memiliki efek untuk membimbing user dengan cara yang personal untuk memilih objek yang menarik dan berguna di antara banyaknya kemungkinan pilihan yang bersifat multi kriteria. Pengolahan data dilakukan dengan pendekatan metode Promethee, dikarenakan keunggulan yang dimiliki teknik analisa ini yaitu kesatuan model tunggal yang mudah dimengerti, mampu memecahkan persoalan yang komplek, serta dapat menangani saling ketergantungan elemenelemen dalam sistem dan tidak memaksakan pemikiran yang linear. Berdasarkan pemilihan program studi kriteria, subkriteria yang diperlukan untuk menunjang alternative sebagai sistem penunjang keputusan. Berdasarkan hasil analisa penentuan keputusan pemilihan jurusan FMIPA dapat diketahui bahwa metode Promethee dapat digunakan sebagai alternatif metode dalam menentukan pemilihan jurusan dengan tepat. Hasil analisa menggunakan Promethee berdasarkan data sampel hasil survei menunjukan bahwa jurusan yang paling banyak di minati calon mahasiswa yang dipilih secara random adalah jurusan Fisika dengan mengutamakan karir untuk masa depannya.

Aplikasi Recommender System dapat memberikan informasi dan recommendasi pilihan sebaik mungkin sehingga dapat membantu mahasiswa baru dalam pemilihan program studi secara langsung. Penggunaan Recommender System ini dapat menghasilkan keputusan yang sangat cepat pada saat responden mengisi pemilihan program studi, sedang penggunaan aplikasi manual menggunakan expert chiose responden tidak dapat mendapatkan hasil secara langsung atau dengan cepat. 


\section{UCAPAN TERIMAKASIH}

Terimakasih kepada mahasiswa 11.6A STMIK Nusa Mandiri yang telah membantu penelitian ini terlaksana dengan baik.

\section{REFERENSI}

[1] G. Adomavicius, et al, "Toward the Next Generation of Recommender Systems: A Survey of the State of the Art and Possible Extensions". IEEE Transactions on Knowledge and Data Engineering, 2005

[2] R. Akhiro, "Tesis: Multi Criteria Decision Making (MCDM) Study for Job Market Place Recommender System, JBPTITBPP”, Central Library Institute Technology Bandung. 2008.

[3] P. W. Bridgman, Dimensional Analysis, New Haven: Yale University Press, CN. 1922.

[4] F. Nur, "Skripsi: Faktor-Faktor Internal Yang Mempengaruhi Mahasiswa Fakultas Ekonomi Dalam Memilih Jurusan Ekonomi Pembangunan Di Fakultas Ekonomi Universitas Negeri Malang”, 2007.

[5] J. Fulop, Introduction to Decision Making Methods. Laboratory of Operations Research and Decision Systems, Computer and Automation Institute, Hungarian Academy of Sciences, 2007.

[6] R. Harris, Introduction to Decision Making, Virtual Salt, 1998.

[7] N. Manouselis, et al, "Analysis and Classification of Multi-Criteria Recommender System. World Wide Web: Internet and Web Information Systems, Special Issue on Multi-channel Adaptive Information System on the World Wide Web”. Springerlink. 2007.

[8] Z. Purnamawati.”Skripsi: Analisis Pengaruh Faktor Internal Dan Faktor Eksternal Terhadap Minat Mahasiswa Berwirausaha”, Universitas Diponegoro. Semarang, 2009.

[9] M. A.Setiawan, "Tesis: Sistem Pendukung Keputusan dengan Metode Promethee Untuk Penentuan Pemenang Tender (Studi Kasus Pengadaan Bahan Habis Pakai di Politeknik Negeri Malang)”, Ilmu Komputer UGM, Yogyakarta, 2006.

[10] F. M. Tampake, (2007), “Tesis: Sistem Pendukung Keputusan Penentuan Pendirian SPBU Berbasis Web dengan Menggunakan Metode Promethee”, Ilmu Komputer UGM, Yogyakarta, 2007.

[11] E. Faizal, “Analisis pemilihan Jurusan Favorit menggunakan metode Promethee (Studi Kasus pada STMIK El Rahma Yogyakarta)”, FAHMA - Jurnal Teknologi Informasi dan Ilmu Komputer, Vol. 13 No. 2, Mei 2015.

[12] B. Yuwono, dkk, "Sistem pendukung Keputusan Menggunakan metode Promethee (studi kasus stasiun pengisian bahan bakar umum)”, Telematika, Vol. 8 No. 1, pp. 63-74, JULI 2011. 
